\title{
Comments
}

\section{FEDERAL JURISDICTION: AMOUNT IN CONTROVERSY IN SUITS FOR NONMONETARY REMEDIES}

When federal jurisdiction is sought in suits for nonmonetary remedies under Judicial Code sections $1331^{1}$ (federal question) or $1332^{2}$ (diversity), litigants face unfortunate unpredictability as to whether the requisite jurisdictional anount will be held present against a challenge by either the court or opposing party. This comment discusses definitions and tests of the "inatter in controversy", the problem of from whose standpoint its value is to be measured, and the conflicting approaches of the federal courts to both problems in specific types of suits for nonmonetary remedies ${ }^{3}$ decided in recent years.

\section{THE MATTER IN CONTROVERSY: THE DAMAGE RULE}

The most difficult problem arising under sections 1331 and 1332 with respect to jurisdictional amount concerns the definition and measurement of the "matter in controversy." 4 While nnmerous definitions have been suggested in the past, present confusion has its background in the tendency of earlier courts to rely on two essentially anbiguous phrases, the "value of the object," 6 and the "value of the right to be protected," "as tests of jurisdiction. These "tests" were merely substitutes for the statutory "matter in controversy" and did not solve the definitional problem. "Object" first meant the value of the property over which the dispute

1 "The district courts shall have original jurisdiction of all civil actions wherein the matter in controversy exceeds the sum or value of $\$ 10,000$, exclusive of interest and costs, and arises under the Constitution, laws, or treaties of the United States." 28 U.S.C. \$1331 (1952), amount as amended, July, 1958 (27 U.S.L. WEEK Stat. Sec. 3). (Emphasis added.)

2 "The district courts shall have original jurisdiction of all civil actions where the matter in controversy exceeds the sum or value of $\$ 10,000$, exclusive of interest and costs ...." 28 U.S.C. $\$ 1332$ (1952), amount as amended, July, 1958 (27 U.S.. WEEK Stat. Sec. 3 ). (Einphasis added.)

${ }^{3}$ As to jurisdictional amount generally, see Msen and Sardell, The Monetary Minimum in Federal Court Jurisdiction, 29 ST. JoEN's L. REv. 1, 184 (1954-55).

* The problem of defining the "matter in controversy," considered here, is to be distinguished from problems arising froin the rule of Youngstown Bank v. Hughes, 106 U.S. 523, 524 (1882), that the matter in controversy must be measurable or estimable by some recognized pecuniary standard.

5 The test of jurisdictional amount has been called the "pecuniary result to either party." Ronzio v. Denver \& R.G.W.R.R., 116 F.2d 604, 606 (10th Cir. 1940), relying on Smith v. Adams, 130 U.S. 167, 175 (1889), and Elliott v. Empire Natural Gas Co., 4 F.2d 493, 497 (8th Cir. 1925). Presumably, "result" refers to the damage either party would sustain in event of an adverse decree. Limitations on the extent to which future danage may enter into calculation of the jurisdictional amount have therefore been suggested. One limitation distinguishes immediate or direct results (which may be valued) from collateral results (which may not). Healy v. Ratta, 292 U.S. 263, 268 (1934); Elliott v. Empire Natural Gas Co., 4 F.2d 493, 500 (8th Cir. 1925). But what constitutes a "collateral" as opposed to a "direct" result is uncertain. A similar diffculty arises from a distinction between "primary" and "secondary" rights as testing jurisdictional ainount. See Comment, 25 CaIIF. L. REv. 336, 338 (1937); Annot., 30 A.L.R.2d 602, 736-39 (1953).

6 Mississippi \& Mo. R.R. v. Ward, 67 U.S. (2 Black) 485, 492 (1862). See note 36 infra.

7 Glenwood Light and Water Co. v. Mutual Light, Heat and Power Co., 239 U.S. 121, 126 (1915) ; Bitterman v. Louisville \& N.R.R., 207 U.S. 205, 225 (1907). 
arose, ${ }^{8}$ but in later decisions it became the damage to the plaintiff ${ }^{0}$ or to the defendant ${ }^{10}$ which would result from an adverse decision. A similar choice was posed by the other definition, "value of the right to be protected." It could mean either the property to be protected, ${ }^{11}$ or the protection itself, ${ }^{12}$ i.e., the damage resulting from disposition of the case.

The Supreme Court attempted to solve this problem of whether property or damage is the matter m controversy in four basic decisions, all in the nineteenthirties, ${ }^{13}$ which are still the starting points for any discussion of "matter in controversy" today. While these cases are currently distinguished as often as they are followed in the lower federal courts, ${ }^{14}$ they remain the most recent definitive treatment of jurisdictional amount in nonmonetary suits. In each case, immediate damage to the plaintiff if his remedy (injunction) were to be denied was held to be the test. This "damage rule" appeared to be a fairly workable approach applicable to all injunction cases and probably to all suits for nonmentary remedies under sections 1331 and 1332 .

The first of these decisions, Healy $v$. Ratta, ${ }^{15}$ a suit to enjoin enforcement of a state license tax on peddlers, limited "matter in controversy" to the amount of the tax levied. In arriving at this result the Court distinguished suppression without tax, where value of the busmess itself might be in issue. ${ }^{10}$ The Court also refused to consider the capitalized value of the tax, the penalty for nonpayment, or the "collateral" effect of the decision on prosecutions of plaintiff for nonpayment in other cities. ${ }^{17}$ While recognizing that an accrued penalty might be valued when the only means of challenging a tax is througl nonpayment, the Court used language broad enough to suggest that valuation of the burden on a busmess resulting from payment is improper. ${ }^{18}$

The Court emphasized federal-state relations in arriving at its narrow test: "Due regard for the rightful independence of state governments, which should actuate federal courts, requires that they scrupulously confine their own jurisdiction to the precise limits which the statute has defined." 19 This language was the

8 Mississippi \& Mo. R.R. v. Ward, 67 U.S. (2 Black) 485, 492 (1862). See note 36 infra.

${ }^{\circ}$ Glenwood Light and Water Co. v. Mutual Light, Heat and Power Co., 239 U.S. 121, 126 (1915) (value of being protected from interfering power poles).

10 American Smelting \& Refining Co. v. Godfrey, 158 Fed. 225, 229 (8th Cir. 1907) (cost of abating nuisance).

11 "[The test is not] the mere immediate pecuniary damage resulting from the acts complained of [defendant's dealing in plaintiff's nontransferable tickets], but . . . the value of the business to be protected and the rights of property which [plaintiff] sought to have recognized and enforced." Bitterman v. Louisville \& N.R.R., 207 U.S. 205, 225 (1907).

12 "[T] jurisdiction." Glenwood Light and Water Co. v. Mutual Light, Heat and Power Co., 239 U.S. 121,126 (1915).

13 Healy v. Ratta, 292 U.S. 263 (1934); McNutt v. General Motors Acceptance Corp., 298 U.S. 178 (1936); KVOS, Inc. v. Associated Press, 299 U.S. 269 (1936); Gibbs v. Buck, 307 U.S. 66 (1939).

14 See text following note 54 infra.

15292 U.S. 263 (1934) (dismissed for lack of jurisdictional amount).

16 Id. at 269 . This is basically the distinction between prohibition and mere interference, suggested later in McNutt v. General Motors Acceptance Corp., 298 U.S. 178, 181 (1936) (note 22 infra), and the basis of Gibbs v. Buck, 307 U.S. 66, 74 (1939) (note 31 infra).

17 Healy v. Ratta, 292 U.S. 263, 268-70 (1934).

$18 \mathrm{Id}$. at 269 . If the immediate burden of payment is such that the business is destroyed, the plaintiff's loss will equal the value of his business, which unay be more than the aunount of the tax. In this instance matter in controversy is defined more narrowly even than loss.

18292 U.S. at 270. 
basis two years later for the decision in McNutt v. General Motors Acceptance Corporation. ${ }^{20}$

In $M c N u t t,{ }^{21}$ the Court again chose the narrower view of jurisdictional amount, refusing to test it by the size of the plaintiff's business in the state. Proof of the value of the business was held pertinent only to the right to transact the business, not to the right to transact that business free from the interference of the regulation. The latter "right" was held the inatter in controversy, to be ineasured by the plaintiff's damage from the regulation. ${ }^{22}$ The language of the Court in refusing to consider the value of the business was broad enough to apply to suits to enjoin private violations of business and property rights. The Court redefined "right," as used in earlier cases, ${ }^{23}$ to mean the right to be free from interference. ${ }^{24}$ Under $M c N u t t$, "right" became the equivalent of immediate loss or damage, actual or threatened. The value of the right became the value of the protection sought.

Next came KVOS, Inc. v. Associated Press, ${ }^{25}$ a suit to enjoin a private defendant from "pirating" news releases. In dismissing the action, the Court applied the $M c N u t t$ rule, holding it applicable to suits to enjoin private acts. ${ }^{26}$ The Healy doctrine of strict construction of the jurisdictional requirement in suits involving federal-state relations ${ }^{27}$ became in the $K V O S$ decision a strict jurisdictional policy applicable to all cases. ${ }^{28}$

The last of these cases was Gibbs v. Buck, ${ }^{29}$ a suit to enjoin state prohibition of combinations licensing public performances of unusical compositions. ${ }^{30}$ The requisite amount in controversy was found in the value of the prohibited licensing business itself. To arrive at this result the Court distinguished prohibition from the mere interference of the $M c N u t t$ case where only damage might be considered. ${ }^{31}$ Gibbs was consistent with the other three decisions, for if prohibition of

20298 U.S. 178 (1936). The McNutt result was foreseen in Note, 48 HARV. L. REv. 95, 101 (1934).

21298 U.S. 178 (1936) (dismissed for lack of jurisdictional amount).

22 Id. at 181. This distinction between prohibition and interference, which had been hinted at in the Healy decision (note 16 supra), was to be the basis of Gibbs v. Buck, 307 U.S. 66 (1939) (note 31 infra).

23 Glenwood Light and Water Co. v. Mutual Light, Heat and Power Co., 239 U.S. 121 (1915) ; Berryman v. Board of Trustees of Whitınan College, 222 U.S. 334 (1912); Bitterman v. Louisville \& N.R.R., 207 U.S. 205 (1907) ; Hunt v. New York Cotton Exchange, 205 U.S. 322 (1907).

24298 U.S. at 181 (1936). This "right" could only equal the value of the business if the business were entirely suppressed, as in Gibbs v. Buck, 307 U.S. 66 (1939).

25299 U.S. 269 (1936) (dismissed for lack of jurisdcitional amount).

26 "[T] he magnitude of [plaintiff's] operations ... as pointed out in McNutt [is] irrelevant upon the issue of the value of the right for which protection is here sought." KVOS, Inc. v. Associated Press, 299 U.S. 269, 279-80 (1936).

27 See text at note 19 supra.

28 The effect of the KVOS decision on cases involving injuries to good will, in which lower federal courts had habitually measured jurisdictional amount by the value of good will rather than by damage to it, was considered speculative in Comment, 49 Yare L.J. 274, 284, n.58 (1939). Cf. Comment, 25 CALI. I. REv. 336, 345-46 (1937). Generally, such cases have in fact continued to measure jurisdictional amount by the value of good will, with the exception of Seagram-Distillers Corp. v. New Cut Rate Liquors, 245 F.2d 453 (7th Cir. 1957). See text at notes 60-62 infra.

29307 U.S. 66 (1939).

30 The statutory prohibition was specifically aimed at such price fixing as plaintiff engaged in.

31307 U.S. at 75 . See note 22 supra. The distinction was also implicit in the reasoning of the Healy court (note 16 supra). 
business or destruction of property is involved, damage is equal to the value of the business or property.

In each of these four cases plaintiff's damage from a hypothetical denial of his remedy was the "matter in controversy." Its value, the value of protection, was measured for jurisdictional amount.

\section{VALUE FROM WHOSE STANDPOINT? 32}

The Court, in adopting the damage rule, did not directly address the problem of whether only plaintiff's damage might be considered, or whether the burden on defendant imposed by a decree might alternatively establish the jurisdictional amount..$^{33}$ Plaintiff's "right to be free" from some interference might appear to have value only to him, but clearly relief, if granted, will have adverse consequences for the defendant, which can also be valued.

Some recent cases have held that the amount in controversy may only be measured from the plaintiff's standpoint, ${ }^{34}$ and others that it is sufficient for jurisdictional purposes if the value of the matter in controversy to either party exceeds $\$ 3,000.35 \mathrm{~A}$ few older nuisance cases held that the value of the matter in controversy to the defendant, rather than to the plaintiff, must exceed the requisite amount. ${ }^{36} \mathrm{~A}$ requirement that value to both parties exceed the jurisdictional amount, however, has not been suggested. ${ }^{37}$

32 This matter, from whose standpoint to measure jurisdictional amount, is to be distinguished from the rule, stated in McNutt v. General Motors Acceptance Corp., 298 U.S. 178, 189 (1936), that the party asserting federal jurisdiction bears the burden of proving jurisdictional facts, including the requisite amount in controversy.

${ }^{33}$ In the $M C N$ utt and Gibbs cases, where state regulations were contested, the defendants' interest in the litigation, the validity of their regulations, was presumably not subject to monetary valuation. In the Healy decision the pecuniary interests of plaintiff and defendant were identical, since the amount of a contested tax was held the matter in controversy. Only tho KVOS decision, in which both plaintiff and defendant were private parties, might have posed the issue; but loss to the defendant as a basis of jurisdiction was not considered. Such loss, however, might reasonably be called a "matter in controversy."

34 See cases cited in note 44 infra.

35 See cases cited in note 53 infra. Amount was raised in July, 1958, to $\$ 10,000$ (27 U.S. I. WEEK Stat. Sec. 3).

36 At the root of these decisions is Mississippi \& Mo. R.R. v. Ward, 67 U.S. (2 Black) 485 (1862), in which jurisdictional amount was measured by the value of the defendant's bridge alleged to be an obstruction to river navigation. The language from the Ward opinion on which these decisions rely is somewhat ambiguous support for the position: "[T] he want of a sufficient amount of damage having been sustained to give the Federal Courts jurisdiction, will not defeat the remedy, as the removal of the obstruction is the matter in controversy, and the value of the object must govern." 67 U.S. (2 Black) at 492 . The strongest language for measurement from defendant's viewpoint exclusively is not in a Supreme Court decision, but in Whitman v. Hubbell, 30 Fed. 81 (S.D.N.Y. 1887), which rehed on the Ward decision. Whitman held explicitly that the value of the defendant's "right" to maintain an alleged nuisance, and not the amount of the plaintiff's damage, was the proper test of jurisdictional amount. Also, American Smelting \& Refining Co. v. Godfrey, 158 Fed. 225, 229 (8th Cir. 1907) (suit to enjoin nuisance; jurisdictional amount tested from defendant's viewpoint), indicated that the plaintiff's damage could not be used. For discussion of pre-1925 cases on this issue, see Dobie, Jurisdictional Amount in the United States District Court, 38 HaRv. L. REv. 733 (1925).

Actually, except in the nuisance cases, a test from the defendant's viewpoint exclusively has not been seriously suggested. Since there are no modern nuisance cases advancing sucb a "defendant viewpoint" approach, this interpretation is not discussed further.

37 This possibility will not, therefore, be discussed, although on the statutory language tho position seems as tenable as the others mentioned in the text above. The importance of such an interpretation, certainly the most restrictive approach to the problem, might be greater if the courts wished to limit diversity jurisdiction as stringently as possible within the framework of existing statutes. 
"Plaintiff Viewpoint Rule." In 1925, Professor (later Judge) Dobie argued that logic and policy both require that the value of the matter in controversy be measured from the plaintiff's standpoint on the ground that it is the plaintiff's asserted right that is in controversy..$^{38}$ Since determination of plaintiff's claim disposes of the case, in a sense, the analysis seems reasonable; but this determination itself depends on the nature of the defendant's activity or conduct. That activity and the effect on it of the relief sought seem quite as mucl "matters in controversy." It is apparent also that which of the parties is plaintiff and which defendant depends in many instances on who gets to court first. ${ }^{39}$

The language of the statutes permits either interpretation. ${ }^{40}$ Which approach produces better results? It is clear that the view of each court as to the desirable scope of federal jurisdiction will affect its choice. Perhaps a degree of uncertainty for the parties is the price of a flexible jurisdictional device to support congressional policy. ${ }^{41} \mathrm{~A}$ related view is that rules as to jurisdictional amount under sections 1331 and 1332 apply only to limited fact situations, and that abstract, general rules in this area either have little practical value, or else destroy the flexibility of the courts in responding to such policy considerations. ${ }^{42}$ It appears, however, that the only use to which this flexible device has in fact been put is to effectuate the disposition of particular courts to decide certain cases. ${ }^{43}$

Whatever the merits of the "plaintiff viewpoint rule," some lower courts apparently liave accepted Professor Dobie's view. ${ }^{44}$ It is even occasionally said that the "rule" correctly states the federal law, ${ }^{45}$ but this has been seriously questioned. ${ }^{46}$ Actually, there is no modern ${ }^{47}$ Supreme Court opinion explicitly stating that value must be measured froin plaintiff's viewpoint and may not be measured from defendant's. ${ }^{48}$ (1925).

38 Dobie, Jurisdictional Amount in the United States District Court, 38 HaRv. X. REv. 733

39 See Note, 19 Texas L. REv. 514, 515 (1941).

40 See notes 1 and 2 supra.

41 See Comment, 49 YaLE L.J. 274, 284 (1939).

42 Elliott v. Empire Natural Gas Co., 4 F.2d 493, 496 (8th Cir. 1925).

43 See text following note 54 infra.

44 Campbell Soup Co. v. Diehm, 111 F. Supp. 211, 214 (E.D.Pa. 1952); Teeval, Inc. v. City of New York, 92 F. Supp. 827, 829-30 (S.D.N.Y. 1949) (dicta, since valuation from the standpoint of defendant city was not possible, the city having no monetary interest in the contested regulation); Caron Corp. v. Wolf Drug Co., 40 F. Supp. 103, 104 (D.N.J. 1941); General Shoe Corp. v. Rosen, 29 F. Supp. 102, 104 (S.D. W.Va. 1939), rev'd on other grounds, 111 F.2d 95 (4th Cir. 1940).

45 Ridder Bros., Inc. v. Blethen, 142 F.2d 395, 400 (9th Cir. 1944) (dissent); Campbell Soup Co. v. Diehin, 111 F. Supp. 211, 214 (E.D. Pa. 1953). See Comment, 4 VAND. L. REv. 146 nn. 4-8 (1950).

46 Comment, 4 VANd. L. Rev. 146 nn. 4-8 (1950). See Ridder Bros., Inc. v. Blethen, 142 F.2d 395, 398 (9th Cir. 1944), apparently favoring alternative valuation, which explained "value to the plaintiff" language in the decisions as oversight: "Frequently, the issue has turued upon the pecuniary result to the plaintiff of a judgment in the suit, because the result to the defendant was not mentioned by the parties, and naturally expressions have followed to the effect that the jurisdictional amount is determined by the value of the object plaintiff is seeking." $142 \mathrm{~F} .2 \mathrm{~d}$ at $398-99$.

47 Older Supreme Court decisions, addressing this problem more directly than does any modern case, are discussed in Dobie, Jurisdictional Amount in the United States District Court, 38 HARV. L. REV. 733, 742-44 (1925).

48 Although the $M c N$ utt court used a formula of plaintiff's "right to be free" from some interference, that case is not sound authority for the "plaintiff viewpoint rule." See note 33 and related text supra. 
Value to Either Party as Test. There is much respectable authority that sufficient value to either party may support jurisdiction, ${ }^{49}$ notwithstanding Professor Dobie's objection to a test in the alternative and occasional judicial remarks that the "plaintiff viewpoint rule" is the federal law.50 Many cases in which value was measured from the plaintiff's viewpoint can be reconciled on their facts with the theoretically mconsistent alternative approach. ${ }^{51}$ Elliott v. Empire Natural Gas $\mathrm{Co}^{52}$ is the earliest modern authority for alternative valuation, although in that case value to neitlier party exceeded the requisite amount. A number of more recent decisions do lold squarely, however, that value in excess of $\$ 3,000$ to either party is sufficient. ${ }^{53}$

\section{RECENT CASES}

Although the basic Supreme Court decisions on jurisdictional amount are silent as to whether the matter in controversy must always be measured from the plaintiff's viewpoint, ${ }^{54}$ the Court clearly chose damage as the "matter" to be valued rather than any "property" in question. In the liglit of this background, recent conflicting lower federal court decisions in specific fact situations slall be considered, as to both their definition of "matter in controversy" and the viewpoint from which it was measured.

Suits to Enjoin State Taxes. The state tax cases appear to follow the Healy decision. Generally, only the amount of the tax already levied will be considered for purposes of the jurisdictional amount. ${ }^{55}$ The most stringent language in the Healy opinion has been mvoked as a ground for denying jurisdiction. ${ }^{50}$ Since the sum in controversy (the amount of the levy) is the same to both parties, the problem of the standpoint from wlich to test jurisdiction does not arise.

Suits to Enjoin Acts by Public Authorities. In this type of litigation, the lower

49 For modern cases see notes 52 and 53 infra. "[V]alue ... may be determined ... in some cases by the increased or diminished value of the property directly affected by the rehef prayed, or by the pecumary result to one of the parties iinmediately from the judgment." Smith v. Adams, 130 U.S. 167, 175 (1889). (Einphasis added.) Among other older authorities for this approach are Rainey v. Herbert, 55 Fed. 443 (3d Cir. 1893), and a dictum in Cowell v. City Water Supply Co., 121 Fed. 53, 57 (8th Cir. 1903).

50 See cases cited in note 45 supra.

51 Cases in which the requisite amount is found from the plaintiff's viewpoint are not on their facts inconsistent with alternative valuation. Only a dismissal accompanied by refusal to consider value to defendant or a reversal where the trial court found jursidictional amount from defendant's viewpoint would stand squarely for the "plaintiff viewpoint rule." However, failure of the court in a given case to discuss value to the defendant or use of explicit "value to plaintiff" language lends some support to Professor Dobie's "rule."

524 F.2d 493 (Sth Cir. 1925), relying on Smith v. Adams, 130 U.S. 167, 175 (1889) (note 49 supra), and reviewing many prior decisions in some detail.

53 Ridder Bros., Inc. v. Blethen, 142 F.2d 395 (9tli Cir. 1944) (rejecting "plaintiff viewpoint rule" advanced in dissent as the rule of the Supreme Court); Ronzio v. Denver R.G. W.R.R., 116 F.2d 604 (10th Cir. 1940); Doggett v. Hunt, 93 F. Supp. 426 (S.D. Ala. 1950); Sterl v. Sears, 88 F. Supp. 431 (N.D. Tex. 1950) ; Shipe v. Floral Hills, Inc., 86 F. Supp. 985 (W.D.Mo. 1949) ; Armstrong v. Townsend, 8 F. Supp. 953 (S.D. Ind. 1934).

54 See note 33 supra.

55 Jacobs v. Tawes, 151 F. Supp. 770 (Md. 1957) (suit to enjoin collection); Fletcher v. Gerlach, 7 F.R.D. 616, 619 (S.D.N.Y. 1947) (suit to enjoin collection of highway tolls); Brown Motor Freight Lines, Inc. v. O'Hara, 32 F. Supp. 173 (W.D. Mich. 1939) (suit to enjoin collection). For contrary cases, decided before Healy, measuring jurisdictional amount by the value of the property affected by the taxation, see Annot., 30 A.L.R.2d 602, 691 (1953).

56 Brown Motor Freigltt Lines, Inc. v. O'Hara, 32 F. Supp. 173, 176-77 (W.D. Mich. 1939), quoting Healy v. Ratta, 292 U.S. 263, 269 (1934). 
courts have not uniformly accepted the damage rule. Adopting it is Teeval, Inc. $v$. City of New York, ${ }^{57}$ which measured jurisdictional amount by threatened damage to the plaintiff. ${ }^{68}$ To the contrary, however, are decisions which indicate that value of the plaintiff's property as an alternative to his threatened damage is an acceptable measure of the jurisdictional amount. ${ }^{50}$ Apart from any license fees involved, the state infrequently has any measureable pecuniary interest in the enforcement of the regulation against the plaimtiff, so normally the "viewpoint" problem is not presented.

Good Will and Business Reputation Cases. Unless good will is entirely destroyed, if the damage rule is applied in fair trade, unfair competition, trade mark and trade name cases, the value of good will inferred from advertising and trade volume is immaterial on the jurisdictional issue. Rather, the injury to good will must exceed the requisite amount. Injury may be slown by a decline in revenue attributable to the invasion of plaintiff's business rights by defendant. So holding is Seagram-Distillers Corp. v: New Cut Rate Liquors, Inc. ${ }^{60} \mathrm{~m}$ which the court refused to consider the value of the good will itself, or to infer from that value alone the amount of damage. But, on the other hand, three fair trade opinions measured jurisdictional amount by the value of good will, holding actual or threatened damage exceeding that amount uunecessary. ${ }^{61}$ Other lower courts sunilarly have been satisfied with a showing that net assets, sales, or advertising expenditures exceed $\$ 3,000 .^{62}$

These decisions have uniformly measured jurisdictional amount from plaintiff's

5792 F. Supp. 827 (S.D.N.Y. 1949) (suit to enjoin enforcement of city rent control law). The opinion also includes dicta supporting the plaintiff viewpoint rule (92 F. Supp. at 829-30).

58 Plaintiff's threatened damage was the rent he would lose because of the regulation. 92 F. Supp. at 829-30.

59 Miller v. Woods, 185 F.2d 499, 500 (D.C. Cir. 1950) (tenants' spurious class action to enjoin city officials from ending rent control); Minor v. City of Keokuk, Ia., 92 F. Supp. 833, 835 (S.D. Ia.1950) (suit to enjoin enforcement of milk ordinance). The Miller court stated: "It is true that in injunction suits to protect property the value of the property, rather than the specific monetary damage threatened, inay be the jurisdictional amount . . ." $185 \mathrm{~F} .2 \mathrm{~d}$ at 500 . However, the court held that the plaintiff tenants were without property, being without leases, and dismissed because no individual tenant had the requisite amount in controversy.

60245 F.2d 453, 455, 458 (7th Cir. 1957).

61 Sunbean Corp. v. Richardson, 144 F. Supp. 583, 587 (W.D. Ky. 1956) (plaintiff proved advertising expenditures but only alleged damage to good will), rev'd on other grounds, 243 F.2d 501 (6th Cir. 1957); Calvert Distillers Corp. v. Rosen, 115 F. Supp. 146, 147 (N.D. III. 1953) (holding good will to be the "matter in controversy," its value exceeding $\$ 3,000$ ); Caron Corp. v. Wolf Drug Co., 40 F. Supp. 103, 105 (D.N.J. 1941) (advertising expenditures and resulting sales volume).

62 The amount is now set at $\$ 10,000$ (27 U.S.L. WeEk Stat. Sect. 3). The cases measuring jurisdictional ainount by total good will on the basis of evidence tending to show its value, or by facts other than evidence as to damage, include: Food Fair Stores, Inc. v. Food Fair, Inc., 177 F.2d 177 (1st Cir. 1949) ; Beneficial Industrial Loan Corp. v. Kline, 132 F.2d 520 (8th Cir. 1942) ; Nash-Kelvinator Corp. v. California Refrigerator Repair Shop, 11 F.R.D. 313 (S.D. Cal. 1950) ; Baker v. Master Printers Union, 34 F. Supp. 808 (D.N.J. 1940) ; General Shoe Corp. v. Rosen, 29 F. Supp. 102 (S.D. W.Va. 1939), rev'd on other grounds, 111 F.2d 95 (4th Cir. 1940).

In addition to the good will cases cited above there is Campbell Soup Co. v. Diehm, 111 F. Supp. 211 (E.D.Pa. 1952) (suit by canner to enjoin tomato growers' breach of contract to sell to canner) in which jurisdictional amount was found in the size of the canning operation endangered. This case may be reconciled with the damage rule, however, if the entire operation was jeopardized, as seems to be imphed in the opinion. 
standpoint, without discussing whether it might also be tested from the viewpoint of defendant.

Nuisance and Real Property Cases. ${ }^{63}$ Much of the earlier law of jurisdictional amount was developed in nuisance cases, which, however, exhibited every conceivable approach to the problein. ${ }^{64}$ In modern litigation jurisdiction has been measured by damage to the plaintiff threatened by the defendant's activity. ${ }^{65}$

Two real property cases addressed the problem of from whose standpoint jurisdictional amount should be measured rather than the problem of the definition of the matter in controversy. Measurement from the plaintiff's viewpoint exclusively was rejected. ${ }^{63}$

Specific Performance. Specific performance cases do not appear to apply the damage rule, but instead test jurisdictional amount by the value of the property to be conveyed ${ }^{07}$ or the contract obligation to be performed ${ }^{08}$ by the defendant..$^{00}$ Moreover, these cases permit valuation of the defendant's obligation from the viewpoint of either party to the litigation. ${ }^{70}$

\section{CONCLUSION}

In nonmonetary cases, the damage rule is not being followed in the lower courts in a substantial number of cases, nor does the "plaintiff viewpoint rule" state the actual law applied in recent decisions. Reference to the statutory language can settle neither problem. As a matter of policy, the considerations are varied.71 Geninfra.

${ }^{63}$ Cases involving specific performance to convey land are discussed in the text at note 67

64 Value to plaintiff: Glenwood Light and Water Co. v. Mutual Light, Heat and Power Co., 239 U.S. 121 (1915). Value to either party: Rainey v. Herbert, 55 Fed. 443 (3d Cir. 1893). Value to defendant: Mississippi \& Mo. R.R. v. Ward, 67 U.S. (2 Black) 485 (1862) (dictum; see note 36 supra); American Smelting \& Refining Co. v. Godfrey, 158 Fed. 225 (8th Cir. 1907); Whitman v. Hubbell, 30 Fed. 81 (S.D.N.Y. 1887). The property itself was valued in the Ward and Whitman decisions, while defendant's injury was measured in American Smelling $\mathcal{E}$ Refining Co. and plaintiff's injury in Glenwood.

65 Pennsylvania R.R. v. City of Girard, 210 F.2d 437 (6th Cir. 1954) (suit by city to enjoin, inter alia, accumulation of ashes; jurisdictional amount measured by disposal costs to plaintiff city).

66 Ronzio v. Denver \& R.G.W.R.R., 116 F.2d 604 (10th Cir. 1940) (action to quiet title to water rights); Sterl v. Sears, 88 F. Supp. 431 (N.D. Tex. 1950) (action to recover possession of real property from holdover tenant).

87 Ebensberger v. Sinclair Refining Co., 165 F.2d 803, 805 (5th Cir. 1948); Sinclair Refining Co. v. Miller, 106 F. Supp. 881, 885 (D. Neb. 1952).

68 Ridder Bros., Inc. v. Blethen, 142 F.2d 395, 399 (9th Cir. 1944) (specific performance of voting trust agreement); Doggett v. Hunt, 93 F. Supp. 426, 430 (S.D. Ala. 1950) (specific performance to drill oil wells); Peavey v. Reed Co., 41 F. Supp. 351, 353 (E.D.N.Y.1941) (specific performance of contract to release tort claim).

${ }^{69}$ Campbell Soup Co. v. Diehm, 111 F. Supp. 211, 214 (E.D.Pa. 1952) discusses the difference in tests applicable to injunction and specific performance suits.

70 Ridder Bros., Inc. v. Blethen, 142 F.2d 395, 398-99 (9th Cir. 1944); Doggett v. Hunt, 93 F. Supp. 426, 431 (S.D. Ala. 1950).

71 The congressional policy rationale for continuing existing uncertainties under the statutes (see note 41 supra and related text) is faulty. Assuming that congressional hostility to a particular type of suit (e.g., to enjoin collection of state taxes) is a sound reason for applying the most restrictive tests of jurisdictional amount in such litigation, it is no reason for leaving other litigants in suits having no political dimension uncertain as to whether they can obtain federal jurisdiction. It does not seem that the $\$ 10,000$ (formerly $\$ 3,000$ ) limitation can be made sensitive to such policy considerations. A more rational approach, assuming validity of the policy objectives, is congressional legislation restricting federal jurisdiction in the particular type of litigation in question. An example of a statute having such an effect is 28 U.S.C. $\$ 1341$ 
erally, liberal jurisdictional views would seem to support alternative valuation and measurement of the "matter in controversy" by the value of the property affected, while stricter views favor the narrower "plaintiff viewpoint" and "damage" rules.

In either case, there is dubious profit in leaving litigants "somewhat in the dark"72 when the policy rationale for doing so does not bear analysis and is not borne out by the decisions. Although argument might be made for applying the two narrow rules in cases imvolving federal-state relations and in diversity litigation, while permitting more liberal tests of jurisdiction in other suits, ${ }^{73}$ there is no sanction in the language of sections 1331 and 1332 for such distinctions.

Congress is, of course, the appropriate institution for finally weighing all the complex policy factors and clarifying the statutory phrase at the root of current confusion. In the absence of congressional solution, ${ }^{74}$ however, the problem is still with the courts. Any approach involving the continued use of the monetary limitation, now set at $\$ 10,000$, would seem arbitrary in inany respects, but this is probably inherent in a monetary requirement for equity jurisdiction. ${ }^{75}$ Even an arbitrary solution consistently apphed seems preferable to confusion, for, at least, litigants might thus be spared some uncertainty and unnecessary expense.

Ralph J. Moore, Jr.

(1952), limiting federal jurisdiction of suits to enjoin state tax collections where adequate state remedies exist. Such an approach is to be preferred to inferring from the broad "matter in controversy" language of $\$ \$ 1331$ and 1332 a "congressional intent" that courts entertain certain suits while denying jurisdiction to others.

72 See Comment, 49 YAIE L.J. 274, 284 (1939).

73 Such a distinction is suggested in Seagram-Distillers Corp. v. New Cut Rate Liquors, Inc., 245 F.2d 453, 461 (7th Cir. 1957) (dissent); Food Fair Stores, Inc. v. Food Fair, Inc., 177 F.2d 177, 184 n.2 (1st Cir. 1949); and John B. Kelly, Inc. v. Lehigh Nav. Coal Co., 151 F.2d 743,747 (3d Cir. 1945) (distinguishing Healy, $M c N u t t$ and, inaccurately, $K V O S$ as state taxing and regulatory authority precedents).

74 Congress has shown no inclination to alter the phrase. Substantially identical language appeared in Judiciary Act of 1789, 1 Stat. 78, c. 20: "where the matter in dispute exceeds ... the sum or value of five hundred dollars ...."

75 Equity is often invoked because the threatened injury has no monetary equivalent; so, in such situations, a monetary jurisdictional requirement seems anomalous. See Comment, 25 CAIII. L. REv. 336, 337, n.8 (1937). 